\title{
Possibilities of current use of non-invasive laser therapy and systemic enzymotherapy in stomatology
}

\author{
Leoš Navrátili, ${ }^{1,}$, Blanka Navrátilová2 ${ }^{2}$ Jiří Knížek $^{4}$, Zuzana Erösová ${ }^{5}$, Hana Fikáčková ${ }^{5}$, \\ Jaroslava Kymplová ${ }^{1,3}$ \\ ${ }^{1}$ University of South Bohemia, Faculty of Social and Health Studies, Department of Radiobiology and Toxicology \\ of The Institute of Radiology, Ceske Budejovice, Czech Republic \\ ${ }^{2}$ Stomatosurgical Department, Prague 2, Czech Republic \\ ${ }^{3}$ Laser Centre THERAP-TILIA, Prague 5, Czech Republic \\ ${ }^{4}$ Czech Academy of Sciences, ITIA, Prague, Czech Republic \\ ${ }^{5}$ Charles University in Prague, First Medical Faculty, Department of Clinical Radiobiology of Biophysical \\ Institute, Praha 2, Czech Republic
}

\begin{abstract}
Summary
There are no doubts about the benefits of non-invasive laser therapy in treating surgical wounds, thanks to its anti-inflammatory, stimulating and analgesic effects. Systemic enzymotherapy is particularly employed due to its thrombolytic, fibrinolytic and antiedema effects. Concurrent use of the two above mentioned treatment modalities exerts a synergistic action. Thus, it is possible to reduce the persistence of the pain as well as the duration of the post-operation period after surgical interventions in the mouth cavity at a statistically highly significant level. Thus, this approach can be recommended for achieving a favourable outcome in most post-operation conditions.
\end{abstract}

Keywords: stomatosurgery - therapeutic laser - systemic enzymotherapy

\section{INTRODUCTION}

Non-invasive laser therapy is currently a well recognized treatment method in stomatology because of its demonstrated analgesic, anti-inflammatory and stimulating effects on the tissue. We have many years of good experience with this method and have achieved results, which were repeatedly presented (Navrátil and Dylevský, 1996, Navrátil and Dylevský, 1997) and which agreed with those from other institutions (Simunovic 2000).

In systemic enzymotherapy, we administer proteolytic enzymes of animal (pancreatin, trypsin, chymotrypsin, amylase, lipase) and plant (papain, bromelain, rutin) origin (Klaschka 1997). In addition to the antiflogistic effect, in systemic enzymotherapy, the antiedematous, fibrinolytic, immunonormalizing, and primary and secondary analgesic effects are used.

Interest in these methods considerably increased when a number of clinical and experimental works demonstrated that certain amounts of hydrolytic enzymes are absorbed even after their peroral administration, without loss of functional activity (Gupta et al. 1985, Nouza and Wald 1995).

Enzymotherapy is indicated in many fields of treatment. In the course of the anti-inflammatory action, enzymes degrade damaged cells and necrotic material and, through the inactivation of mediators and toxic products, they restrict the oedema and pain. Enzymes do not suppress the inflammation, however, they optimize its course by accompanying processes and prevent its the transition into its chronic form (Kameke 1981, Kleine 1997).

In stomatology, proteolytic enzymes have been used since the 1960's, when Varney-Burch (1962) administered perorally trypsin with chymotripsin after teeth extractions with reducing the healing period by fifty percent. The beneficial effect was also described by further authors, who particularly stressed the restriction of the edema development, its rapid receding, rapid absorption of the hematoma and considerable decrease of the pain (Feinman et al. 1967, Fulga et al. 1994). Favourable papain effects were demonstrated by Magnes (1966) in a double-blind study. From the clinical standpoint, a study by 
Vincenze (1991) on 80 patients after surgical interventions in the mouth cavity is of interest. He observed beneficial effects in $88.9 \%$ of patients.

The purpose of our study was to consider, whether the simultaneous use of the two described treatment modalities, which are both characterized by minimum contraindications, is able to increase the treatment efficiency.

Table 1. Outline of indications in particular groups

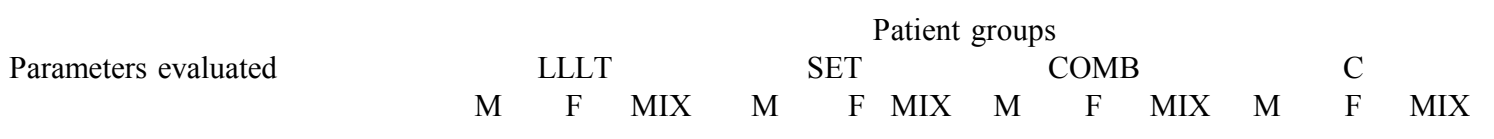

$\begin{array}{lccccccccccccc}\text { number of patients } & \mathrm{n} & 15 & 16 & 31 & 15 & 18 & 33 & 14 & 16 & 30 & 17 & 22 & 39 \\ \begin{array}{l}\text { acute teeth extractions } \\ \text { planned teeth extractions }\end{array} & \mathrm{n} & 5 & 9 & 17 & 6 & 6 & 12 & 7 & 5 & 12 & 8 & 9 & 17 \\ \begin{array}{l}\text { anchorage of pin for tooth } \\ \begin{array}{l}\text { implantation } \\ \text { n }\end{array}\end{array} & \mathrm{n} & 2 & 4 & 8 & 5 & 8 & 13 & 4 & 7 & 11 & 5 & 8 & 13 \\ \end{array}$

SET - systemic enzymotherapy, LLLT - non-invasive laser therapy, COMB - combination of both types of treatment, C - controls, M men, F - women, MIX - men + women

\section{METHODS}

In our study, we considered the antiedematous, analgesic and stimulating effects of treatment by noninvasive lasertherapy and enzymotherapy separately and in combination. Patients were followed up in the course of acute pain as well as planned teeth extractions and after surgical interventions associated with anchoring the pin for tooth implantation (for numbers of patients and indications see Table 1). Based on the stomatologist's examinations, the rate of edema remission compared with the state 24 hours after the application and duration of the treatment (in days) were evaluated and, based on the patient's communication, the time period of persisting pain at the operation according to the patient's subjective opinion, was evaluated. The occurrence of possible complications was taken into account.

The age was recorded in all the patients.

The patients were divided into the following four groups:

LLLT - the laser was applied once daily by the energy density of $4 \mathrm{~J} / \mathrm{cm}^{2}$ until a decrease in problems, maximal number of necessary applications did not exceed 7 ;

SET - the group of patients receiving the enzymatic product alone. Each patient took 3 times daily 2 tablets for 7 days regardless of his body weight. The resorption rate of effective substances has been evaluated;
COMB - the group of patients receiving the enzymatic product and simultaneously being treated with therapeutic laser under the same above mentioned criteria;

C - the control group was treated by standard procedure - by ice application on the operation wound and rinsing with $0,02 \%$ chlorhexidine solution. A laser without diode was applied at the same time. It was not possible to apply a placebo becasue of its high cost..

The patients were divided into groups based on the day of the week, according to the first examination (on Monday, the patients were included into the LLLT group, on Tuesday into the COMB group, in Wednesday into the SET group, on Thursday into the control group).

In acute conditions, the treatment with enzymes or laser was started immediately after the intervention; in planned interventions, the enzymatic products were first administered 48 hours prior to the intervention.

No other form of physical treatment was employed in the patients, however, possible further pharmacotherapy was not required because it was not related to the treatment of the motor apparatus (particularly antihypertensives, coronarodilators, cardioprotectants, contraceptives).

The speed of edema reduction and of healing was evaluated by the attending stomatologist. Pain reduction was evaluated based on data reported by the patients. The day on which the sensitivity at the site of 
the surgical intervention completely disappeared according to the patient was considered as decisive.

BTL 2000 therapeutic laser. The therapeutic laser appliance for non-invasive laser therapy was manufactured by the company Beautyline Technology Laser, Praha. This is a semiconductor laser having its

Table 2. Technical parameters of the BTL 2000 appliance own power source and thus, alternative power supply is possible - connection to the mains or supply from a built-in accumulator. For the technical parameters of the appliance see Table 2.
Laser medium

Operation regime

Frequency

Instrument

Dimensions

Deflection angle

Weight

Power supply

Charging

Laser class
GaAlAs laser diode red $685 \mathrm{~nm}$

power $30 \mathrm{~mW}$, convergent

continuous, pulsed

continuous setting $0.1-5000 \mathrm{~Hz}$

anodized aluminium alloy, laser description

length $135 \mathrm{~mm}$

width $234 \mathrm{~mm}$

height $32 \mathrm{~mm}$

$10^{\circ}$

$0.5 \mathrm{~kg}$

$230 \mathrm{~V} / 50 \mathrm{~Hz}$

built-in accumulator $8 \times \mathrm{NiCd}$

3B

Table 3.Outline of parameters followed and their values in groups followed

\begin{tabular}{|c|c|c|c|c|c|c|c|c|c|c|c|c|c|}
\hline \multirow{2}{*}{$\begin{array}{l}\text { Parameters } \\
\text { evaluated }\end{array}$} & & \multicolumn{12}{|c|}{ Patient groups } \\
\hline & & men & $\begin{array}{l}\text { LLLT } \\
\text { women }\end{array}$ & total & men & $\begin{array}{l}\text { SET } \\
\text { women }\end{array}$ & total & men & $\begin{array}{l}\text { COMB } \\
\text { women }\end{array}$ & total & men & $\begin{array}{c}\mathrm{C} \\
\text { women }\end{array}$ & total \\
\hline $\begin{array}{c}\text { number of } \\
\text { patients }\end{array}$ & $\mathrm{n}$ & 15 & 16 & 31 & 15 & 18 & 33 & 14 & 16 & 30 & 17 & 22 & 39 \\
\hline $\begin{array}{c}\text { age } \\
\text { (years) }\end{array}$ & $\mathrm{x}$ & $\begin{array}{c}45.2 \\
0\end{array}$ & 43.75 & $\begin{array}{c}44.4 \\
5\end{array}$ & 41.13 & 44.50 & $\begin{array}{c}42.9 \\
7\end{array}$ & 40.79 & 38.63 & 39.63 & 41.82 & 41.68 & 41.79 \\
\hline & $\mathrm{s}$ & 4.84 & 7.32 & 7.76 & 8.52 & 9.11 & 9.00 & 9.21 & 9.09 & 9.10 & 8.05 & 8.94 & 8.43 \\
\hline $\begin{array}{l}\text { period of } \\
\text { pain }\end{array}$ & $\mathrm{x}$ & 0.80 & 1.00 & 0.90 & 3.00 & 2.72 & 2.85 & 1.36 & 1.31 & 1.33 & 5.06 & 5.41 & 5.26 \\
\hline (days) & $\mathrm{s}$ & 0.60 & 0.47 & 0.56 & 1.20 & 1.25 & 1.24 & 0.51 & 0.47 & 0.49 & 1.48 & 1.50 & 1.51 \\
\hline $\begin{array}{c}\text { period of } \\
\text { edema }\end{array}$ & $\mathrm{x}$ & 0.93 & 1.13 & 1.03 & 0.73 & 1.00 & 0.88 & 0.43 & 0.38 & 0.40 & 4.76 & 4.82 & 4.79 \\
\hline $\begin{array}{l}\text { persistence } \\
\quad \text { (days) }\end{array}$ & $\mathrm{s}$ & 0.47 & 0.63 & 0.63 & 0.59 & 0.56 & 0.59 & 0.55 & 0.56 & 0.56 & 1.52 & 1.21 & 1.35 \\
\hline $\begin{array}{l}\text { treatment } \\
\text { period }\end{array}$ & $\mathrm{x}$ & 5.53 & 5.50 & 5.50 & 6.07 & 5.17 & 5.57 & 4.57 & 4.56 & 4.57 & 8.71 & 9.27 & 9.03 \\
\hline (days) & $\mathrm{S}$ & 1.02 & 1.09 & 1.09 & 0.90 & 0.81 & 0.97 & 1.01 & 1.14 & 1.12 & 1.40 & 1.82 & 1.72 \\
\hline
\end{tabular}

$\mathrm{n}$ - number of patients followed, $\mathrm{x}$ - mean value, $\mathrm{s}$ - standard error; other symbols as in Table 1 

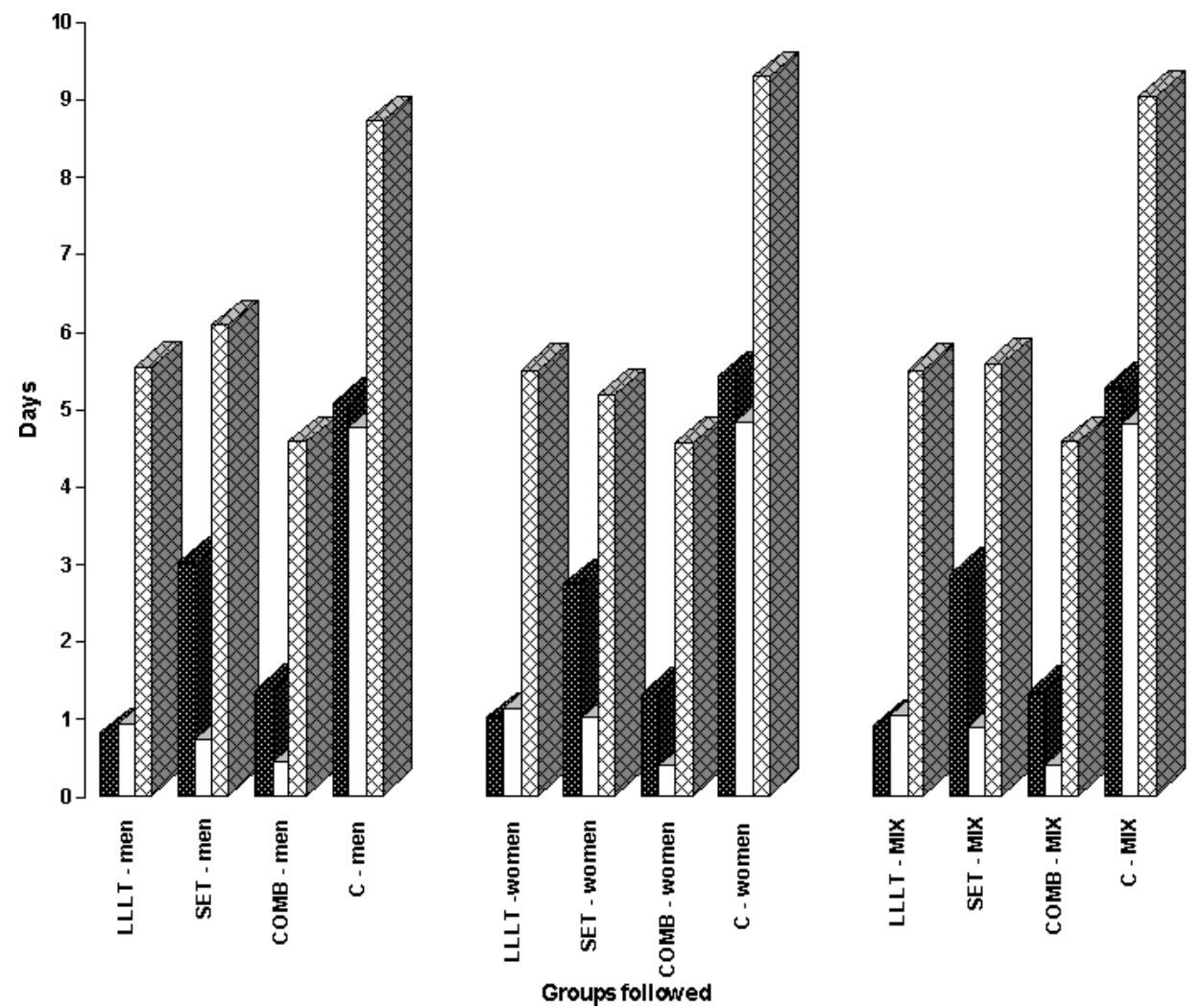

樯 pain period

\section{$\square$ edema \\ period}

国ealing

period

Fig. 1. Duration of evaluated characteristics after surgical wound in mouth cavity. For abbreviations used see explanation under Table 1

Table 4. Statistical significance of differences in age mean values between the groups followed

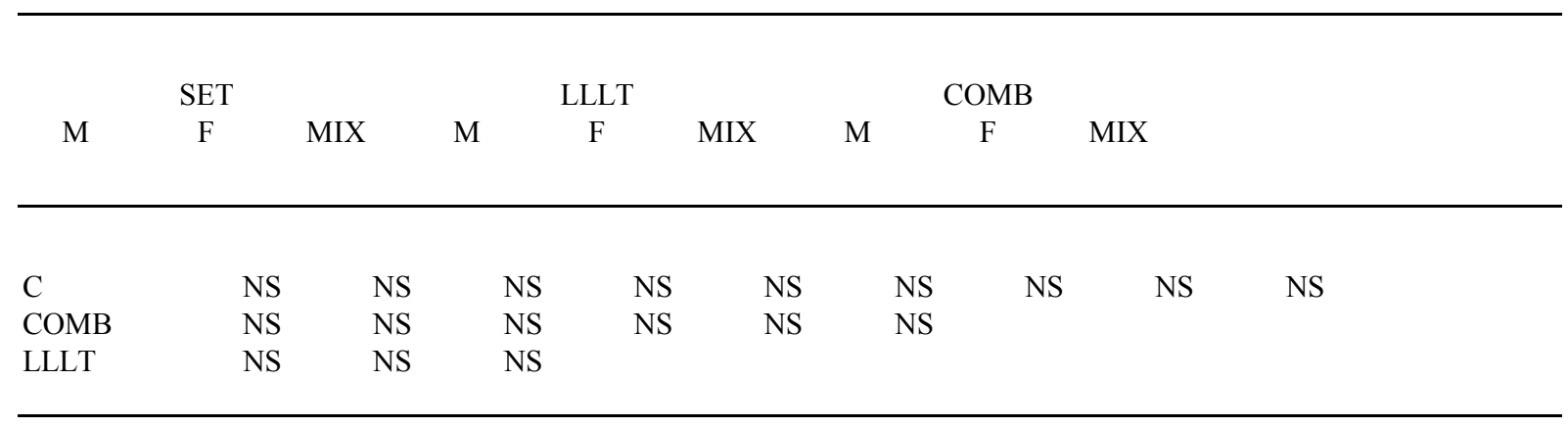

NS - differences statistically not significant; other symbols as in Table 1

Comments. There were no statistically significant differences between age structures of the groups evaluated. 
Table 5. Statistical significance of differences in periods of persisting pain at the site of operation wound between particular groups

\begin{tabular}{|c|c|c|c|c|c|c|c|c|c|}
\hline & \multicolumn{3}{|c|}{ SET } & \multicolumn{3}{|c|}{ LLLT } & \multicolumn{3}{|c|}{ COMB } \\
\hline & M & $\mathrm{F}$ & MIX & M & $\mathrm{F}$ & MIX & $\mathrm{M}$ & $\mathrm{F}$ & MIX \\
\hline $\mathrm{C}$ & * & 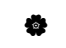 & 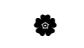 & 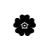 & 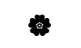 & c & * & * & . \\
\hline COMB & 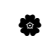 & 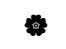 & 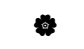 & * & NS & 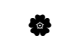 & & & \\
\hline LLLT & 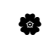 & . & * & & & & & & \\
\hline
\end{tabular}

- differences statistically significant; for other abbreviations used see explanation under Table 1

Comments. The shortest period of persisting pain in the surgical wound region was recorded in the LLLT treated group even (except for the group of women) in comparison with the group with the combined therapy, the difference being statistically significant. The reduction of the period is statistically significant in the COMB group in comparison with the group treated with the SET alone

Enzymatic product composition. In the systemic enzymotherapy, the patients were administered with an enzymatic product containing $48 \mathrm{mg}$ of trypsin (trypsinum), $90 \mathrm{mg}$ of bromelain (bromelaina) and 100 $\mathrm{mg}$ of rutin (rutosidum trihydricum) in each dragée (MUCOS Pharma GmbH und Co., Germany).

Statistics. For the evaluation of results obtained we used the left-sided t-test of the zero hypothesis $H_{0}$, where the hypothesis:

$$
H_{0}: \mu_{1}=\mu_{2}
$$

about the equality of the position parameters $\mu_{1}$ and $\mu_{2}$ of distributions corresponding to random choices with indices 1 and 2 stands against the alternative hypothesis about their inequality:

$H_{A}: \mu_{1}<\mu_{2}$.

The value $\mathrm{p}$ (TTEST) calculated (Knížek et al. 2000) by the TTEST program within the Excel 97 table processor represents the probability of the zero hypothesis validity $H_{0}: \mu_{1}=\mu_{2}$.

\section{RESULTS}

All the parameters followed, including numbers of patients in particular groups and their average age, are summarized in Table 3, individual parameters are also depicted in Figure 1.

The results of the statistical evaluation of comparing particular parameters with the use of the above-specified test, including comments, are presented in Tables 4 to 7 . Groups of men and women and both genders together were evaluated.

Table 6. Statistical difference of the edema period at the surgical wound site between groups followed.

\begin{tabular}{|c|c|c|c|c|c|c|c|c|c|}
\hline & \multicolumn{3}{|c|}{ SET } & \multicolumn{3}{|c|}{ LLLT } & \multicolumn{3}{|c|}{ COMB } \\
\hline & M & $\mathrm{F}$ & MIX & M & $\mathrm{F}$ & MIX & M & $\mathrm{F}$ & MIX \\
\hline $\mathrm{C}$ & 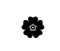 & . & : & 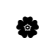 & . & 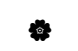 & (4) & (4) & 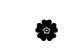 \\
\hline COMB & NS & 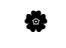 & 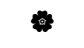 & (4) & . & * & & & \\
\hline LLLT & NS & NS & NS & & & & & & \\
\hline
\end{tabular}

For abbreviations used see explanation under Tab. 1 and 4 


\begin{tabular}{|c|c|c|c|c|c|c|c|c|c|}
\hline & \multicolumn{3}{|c|}{ SET } & \multicolumn{3}{|c|}{ LLLT } & \multicolumn{3}{|c|}{ COMB } \\
\hline & M & $\mathrm{F}$ & MIX & $\mathrm{M}$ & $\mathrm{F}$ & MIX & M & $\mathrm{F}$ & MIX \\
\hline $\mathrm{C}$ & . & . & * & 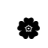 & . & 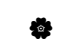 & 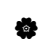 & 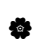 & 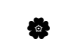 \\
\hline COMB & 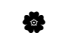 & 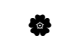 & 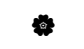 & 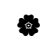 & 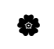 & * & & & \\
\hline LLLT & NS & NS & NS & & & & & & \\
\hline
\end{tabular}

For abbreviations used see explanation under Tab. 1 and 4.

Comments. The treatment period in the group COMB is statistically significantly shorter in comparison with SET and LLLT groups. In contrast to this, the difference between SET and LLLT groups is not statistically significant

\section{DISCUSSION}

In the present work, we considered the possibility of affecting the post-operative outcome after common stomatosurgical interventions, by therapeutic laser, by administering a systemic enzymotherapy product and by their combination.

We repeatedly described beneficial effects of noninvasive laser therapy after stomatosurgical intervention (Ivanov et al. 1990, Navrátil and Navrátilová 2000, Navrátil 2000). In the presented study, we also demonstrated statistically significant reduction of the treatment time with analgesic and anti-inflammatory effects as soon as after 4 to 6 applications at an energy density of $4 \mathrm{~J} / \mathrm{cm}^{2}$.

The administration of products for the systemic enzymotherapy also resulted in a statistically significant reduction of the pain as well as local edema periods and these beneficial effects were reflected by reducing the healing time. This observation is also in agreement with knowledge acquired at other institutions. For example Kameke (1981) described a favorable effect of enzymotherapy in supporting and speeding the biological course of healing and eliminating inflammations (Libický and Nouza 1996, Neretin et al. 1991). The antiedematous effect of the products followed is also present in decreasing the blood density, improving the microcirculation and accelerating the hematoma absorption (Kleine 1997, Magnes 1966). When comparing the present study with the results of Vinzenze (1992), we can see that his observations are even more favorable for enzymatic products than our results.

With respect to the similarity of effects of the two above specified types of therapy having minimum side reactions, we decided to test their combination with the aim of increasing the treatment efficiency.

The results obtained supported our assumption. The combination of these two treatment modalities reduced the length of the pain and healing periods at a statistically highly significant level in all the groups followed.

The persisting pain period after the tooth extraction or pin implantation was shortest after using therapeutic laser alone, even against the group simultaneously treated with SET and LLLT. In men and in the whole group (man + women) this holds even at a statistically significant level. A statistically significant reduction of the pain period was observed in the group treated by LLLT alone in comparison with the SET group. For objective evaluation it is also necessary to emphasize the shorter time of persisting pain after the SET application in comparison with controls.

This result supports our assumption that a combination of the favorable effect of the local vasodilating action of therapeutic laser (Master and Master 1989) described in the literature and SET affecting rheological characteristics (Van Eimeren et al. 1994) with reducing the oncotic pressure and increasing the oxygen partial pressure, brings a beneficial contribution.

It must be empasised that none of the patients in SET and LLLT groups used analgetics. None of them reported pain during the course of the treatment, which would call for using analgetics. This is a valuable finding making it possible to restrict this considerably addicting therapy.

When considering the period of the edema and speed of healing of the operation wound, we found the shortest treatment period after the combined therapy and this period was always significantly shorter in comparison with the use of either non-invasive laser or enzymotherapy alone. The difference in the edema and healing time between therapeutic laser and systemic enzymotherapy was not statistically significant.

The results of the present studies unambiguously demonstrated that the simultaneous use of non-invasive laser therapy and enzymotherapy in indications chosen and in all the parameters followed, considerably 
reduces the period of the edema as well as the period of the pain, thus making possible more rapid convalescence. The knowledge acquired can be used in treating similar indications in all the surgical disciplines.

\section{CONCLUSION}

The present work demonstrated the suitability of combining therapeutic laser and enzymatic products in treating patients after certain stomatosurgical interventions. The study demonstrated a reduction of the oedema period, shorter period of healing and considerable analgesic effect. The chosen physical parameters of non-invasive laser therapy and dosage of enzymotherapy can also be recommended in the treatment in other localities. The knowledge acquired is in agreement with other studies and it suggests that these problems should be studied more deeply.

\section{ACKNOWLEDGEMENT}

This study has been financially supported by Ministry of Education, grant no.: FJ MSM 111100005 (New technologies and approaches in diagnostic, prevention and treatment).

\section{REFERENCES}

Feinman J., J.Sherman, D. McMillan: Oral proteolytic enzymes (pancreatic) in traumatic dental surgery. N. Y. St. dent. J. 33: 336-341, 1967.

Fulga C., I. G.Fulga, M.Predescu: Clinical study of the effect of laser therapy in rheumatoid degenerative diseases. Rom. J. Intern. Med. 32: 227-233, 1994.

Gupta M. K., J. N.Khanna, S. S.Khera: Evalaution of trypsin and chemotrypsin in the management of post-operative oedema. J. Indian dent. Ass. 57: 101-105, 1985.

Ivanov V. V., I. P. Šerbinina, N. M. Bogauri: Primenenie lazernovo izlučenia $\mathrm{v}$ komplexnom lečenii artrozoartritov v usloviach polikliniki. Bul. exp. Biol. Med. 45: 24-26, 1990.
Kaeke E.: Inflammation and its treatment with hydrolytic enzymes and rutin. Abstracts of Forum of the General Practitioner, p. 56-58, 1981.

Klaschka F.: Systemic enzymotherapy (in Czech). Dům medicíny, Praha 1997.

Kleine M. W.: Introduction to oral enzyme therapy. Int. J. Immunother. 13: 59-65, 1997.

Knížek J., J. Österreicher, A. Macela: Probability in t-test in Excel (in Czech). Voj. Zdrav. Listy 69: 206-213, 2000.

Libický A. and K. Nouza: Systemic enzymotherapy (in Czech). Čes. a Slov. Farm. 45: 51-57, 1996.

Magnes G. D.: Proteolytic enzymes in oral surgery. J. Amer. dent. Ass. 72: 1420-1425, 1966.

Mester A. F. and A. Mester: Wound healing. Laser Therapy 1: 7-15, 1989.

Navrátil L. and B. Navrátilová: Possibilities of the treatment of certain diseases in stomatology with the help of noninvasive laser therapy. Progress in Biomedical Optics and Imaging. 37: 273-279, 2000.

Navrátil L. (ed.): Modern phototherapy and laser therapy (in Czech). MANUS, Praha 2000.

Navrátil L. and I. Dylevský: Mechnisms of biostimulating effects of therapeutic laser in vivo. Sborn. lék. 97: 521$527,1996$.

Navrátil L. and I. Dylevský: Mechanism of the analgesic effect of therapeutic lasers in vivo. Laser Ther. 9: 33-40, 1997.

Neretin V. J., V.A. Kurjakov, M.J.Vinogradov, C.V.Kotov, K. I. Savickaja, E. Rusanov: Intraspinalnaja lazeroterapia infekcionnovo mielopoliradikulonevrita. Žurn. Nevrop. Psych. 56: 123-126, 1991.

Nouza K. and M. Wald: Systemic enzymotherapy: To the problem of absorption of enzyme macromolecules (in Czech). Čas. Lék. čes. 134: 615-619, 1995.

Simunovic Z. (ed.): Lasers in medicine and dentistry. DTP studio Vitagrad, Rijeka, 2000.

Van Eimeren W., G. Biehl, K. Tuluweit: Therapie traumatisch verursachter Schwellungen. Adjuvante systematische Therapie mit proteolytischen Enzymen. Gorg Thieme, Stuttgart \& New York 1994.

Varney-Burch M.: An evaluation of an oral antiinflammatory enzyme in dental surgery. Dent. Mag. 2: 102-104, 1962.

Vincenze K.: Ödembehandlung bei zahnchirurgischen Eingriffen mit hydrolytischen Enzymen. Chir. Zahnheilk 7: 1053-1064, 1991.

Vinzenze K and G. Stauder G.: Die Therapie der radiogenen Mukositis mit Enzymen. In: K. Vinzenz and H. W. Waclawiczek (eds). hirurgische Therapie von Kopf-HalsKarzinomen. Springer Verlag, Heidelberg 1992.

Simultaneously published in Kontakt 4, No. 1

\section{Address:}

Leoš Navrátil, Institute of Radiology, Department of Radiobiology and Toxicology, Faculty of Health and Social Care, South Bohemian University, Matice školské 17, 37001 České Budějovice, Czech Republic; leos.navratil@volny.cz 